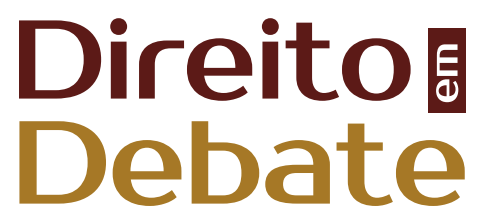

Revista do Departamento de Ciências Jurídicas e Sociais da Unijuí Editora Unijuí - Ano XXX - n. 56 - jul./dez. 2021 - ISSN 2176-6622

\title{
O FETICHE DOS DIREITOS HUMANOS NO CAPITALISMO: A Separação entre a Ética e a Política na Modernidade
}

\author{
http://dx.doi.org/10.21527/2176-6622.2021.56.8450
}

Recebido em: 30/10/2018

Modificações solicitadas em: 2/3/2020

Aceito em: 28/9/2020

João Victor Marques da Silva

Universidade Federal da Bahia. Rua Augusto Viana, s/n - Palácio da Reitoria - Canela, Salvador/BA, Brasil. CEP: 40110-909. http://lattes.cnpq.br/9924535267131067. https://orcid.org/0000-0001-6649-1787. jvmarquesdasilva@gmail.com

\section{RESUMO}

Os direitos humanos ainda se apresentam como uma ferramenta de desenvolvimento humano sob a égide da sociedade burguesa, em que pese a conjuntura atual de intensas e profundas transformações socioeconômicas erigidas em nome da reprodução social do capital. Diante de tal contexto, os direitos humanos perdem força argumentativa e fundamentação prática, o que sinaliza para a necessidade de sua compreensão, a partir da teoria marxiana do valor e do fetichismo, problematizando o seu conceito de ser humano, no âmbito da emancipação do sujeito ético-moral. Para tanto, utiliza-se como método o materialismo dialético e a pesquisa qualitativa como perspectiva de abordagem. Por fim, argumenta-se que o ideário dos direitos humanos no âmbito da sociedade capitalista se apresenta como um discurso fetichizado.

Palavras-chave: Direitos humanos; teoria do valor; fetichismo; emancipação.

\section{THE FETISH OF HUMAN RIGHTS IN CAPITALISM: THE SEPARATION BETWEEN ETHICS AND POLITICS IN MODERNITY}

\section{ABSTRACT}

Human Rights are still presented as a tool for human development under burgeoise society, regardless the current conjuncture of intense and profound socioeconomic changes erected in the name of social reproduction of the capital. Facing this context, Human Rights lose argumentative strength and practical foundation, which is a signal towards the need for their comprehension from the marxian theory of value and fetishism, problematizing their concept of human being, within the emancipation of the ethical-moral subject. For this, dialectical materialism and qualitative research are used as a method of approach. Finally, it is argued that the ideology of Human Rights within the framework of capitalist society presents itself as a fetishized discourse.

Keywords: Human rights; theory of value; fetishism; emancipation. 


\section{CONSIDERAÇÕES INICIAIS}

Os direitos humanos, no discurso da democracia liberal, assumem papel relevante na construção do ideário de desenvolvimento humano sob a égide da sociedade burguesa, servindo como promessa política para o arrefecimento das tensões e contradições provocadas pelas crescentes desigualdades socioeconômicas, ao projetar o seu caráter de universalidade no mundo contemporâneo. Por outro lado, em um contexto atual de crise do Estado burguês, com a naturalização das iniquidades sociais e do exercício cada vez mais limitado da cidadania, por meio da sacralização do capital, os direitos humanos perdem força argumentativa e capacidade de instituição concreta, ainda que nos seus estreitos limites funcionais, o que evidencia o seu discurso como um fetichismo.

Nessa linha, a análise dos direitos humanos no âmbito do capitalismo, a partir da teoria marxiana do valor e do fetichismo, torna-se importante, de um lado, para compreender a sua construção histórica no processo de legitimação da ordem burguesa, como promessa da modernidade, e, de outro, para evidenciar o seu conceito de ser humano sob a ótica da funcionalidade do capital, em detrimento da emancipação do sujeito ético-moral.

Tal construção dos direitos humanos, ao nosso ver, não poderia se concretizar como discurso legitimador da ordem burguesa se não fosse acompanhada da separação entre a ética e a política, na qual foi necessário criar instituições políticas que canalizassem para o bem comum o crescimento e a expansão do interesse privado, fazendo deste o instrumento do interesse público, estabelecendo a adequação da ética privada para fins públicos (CHAUÍ, 2007).

Por outro lado, tal separação entre a ética e a política põe em evidência a problemática da liberdade, pois, de acordo com Hannah Arendt (2006), sem uma esfera pública politicamente garantida, a liberdade fica sem espaço para emergir, uma vez que esta, como fato demonstrável, coincide com a política, e as duas estão intimamente relacionadas.

Assim, o presente ensaio pretende, a partir da teoria marxiana do valor e do fetichismo, analisar os direitos humanos como um ideário de legitimação do capitalismo, problematizando o seu conceito de ser humano como funcional à ordem burguesa, com a finalidade de apontar que a separação entre a ética e a política impede a emancipação do sujeito ético-moral, por Ihe faltar o elemento da liberdade.

\section{A CONSTRUÇÃO DOS DIREITOS HUMANOS COMO FETICHE: A CRÍTICA MARXISTA AO CONCEITO}

Letícia da Costa Paes (2011) afirma que a modernidade introduziu, em contradição à falsa pretensão de uma suposta comunidade universal, uma comunidade dividida em nações e um sujeito igualmente dividido, no qual o sujeito moderno só alcança sua humanidade quando adquire direitos políticos de cidadania, na medida em que pertence à vontade comum do Estado. Ainda, observa que o homem da Declaração de 1789 é uma abstração, universal, mas irreal, observando-se que, ao reproduzir o princípio metafísico do cristianismo, baseado na noção de igualdade e universalidade, os direitos humanos reproduzem, de um lado, o ideal de justiça plena e de um mundo igualitário, e, de outro, expõe esse ideal às circunstâncias reais, às relações desiguais e às diversas formas de opressão e dominação, no exercício dos direitos de cidadania. Na mesma linha, Thamy Pogrebinschi (2007, p. 48) afirma que a separação entre homem e cidadão consiste em uma das consequências nefastas do pensamento político moderno, e um dos engodos mais bem articulados do discurso jurídico pós-Revolução Francesa. Quanto à questão, Karl Marx (2010, p. 48) observa que:

Os droits de l'homme, os direitos humanos, são diferenciados como tais dos droits du citoyen, dos direitos do cidadão. Quem é esse homme que é diferenciado do citoyen? Ninguém mais ninguém menos que o membro da sociedade burguesa. Por que o membro da sociedade burguesa é chamado de "homem", pura e simplesmente, e por que os seus direitos são chamados de direitos humanos? A partir de que explicaremos esse fato? A partir da relação entre o Estado político e a sociedade burguesa, a partir da essência da emancipação política.

Nesse sentido, para Marx (2010), a primeira constatação é o fato de que os assim chamados direitos humanos, os droits de l'homme, diferentemente dos droits du citoyen, nada mais são do que os direitos do mem- 
bro da sociedade burguesa, isto é, do homem egoísta, do homem separado do homem e da comunidade. Para o autor, a segurança é o conceito social supremo da sociedade burguesa, o conceito da polícia, no sentido de que o conjunto da sociedade só existe para garantir a cada um de seus membros a conservação de sua pessoa, de seus direitos e de sua propriedade. Por essa razão, portanto, afirma que nenhum dos assim chamados direitos humanos transcende o homem egoísta, o homem como membro da sociedade burguesa, a saber, como indivíduo recolhido ao seu interesse privado e ao seu capricho privado e separado da comunidade. Ainda, o autor observa que:

Esse fato se torna ainda mais enigmático quando vemos que a cidadania, a comunidade política, é rebaixada pelos emancipadores à condição de mero meio para a conservação desses assim chamados direitos humanos e que, portanto, o citoyen é declarado como serviçal do homme egoísta; quando vemos que a esfera em que o homem se comporta como ente comunitário é inferiorizada em relação àquela em que ele se comporta como ente parcial; quando vemos, por fim, que não o homem como citoyen, mas o homem como bourgeois é assumido como o homem propriamente dito e verdadeiro (MARX, 2010, p. 50).

Nesse sentido, observa Thamy Pogrebinschi (2007) que o Estado nascido da Revolução Francesa declara o individualismo como essência da modernidade e afirma o homem moderno como centro de uma rede de interesses privados que fazem dele um ser autossuficiente e isolado dos demais homens. Assim, no seu entender, a cidadania moderna conferida pelos direitos positivados na Declaração de 1789 transforma a noção de representação, vinculando-a irremediavelmente à propriedade privada, com os direitos humanos passando a ser o discurso por meio do qual, por um lado, se mascara a exploração e a dominação e, por outro, se exprime a luta de classes e a resistência daqueles que são explorados e dominados.

Prossegue a referida autora afirmando que Marx via o evento Revolução Francesa como uma dialética entre o Estado e a sociedade civil, na medida em que a emancipação política supostamente levada a cabo pela burguesia revolucionária francesa consistiu simplesmente na emancipação da sociedade civil em relação à política. Nessa linha, no seu entender, os privilégios feudais são assim substituídos pelo direito, observando-se que é este que passa então a mediar a relação entre os homens, exacerbando sua separação em relação a si próprios e em relação à sociedade em que vivem. Assim, na sua compreensão, o homem egoísta, membro típico da sociedade moderna, passa a ser a base, a premissa do Estado político e, como tal, é reconhecido nos direitos humanos (POGREBINSCHI, 2007).

Não sem razão, diante da cisão entre Estado e sociedade civil, observa Etienne Balibar $(1995$, p. 90) que "os direitos humanos, isolados dos direitos do cidadão, aparecem então como a expressão especulativa da cisão da essência humana, entre a realidade das desigualdades e a ficção da comunidade".

Na mesma linha, de acordo com Letícia da Costa Paes (2011), Marx, ao nos levar à contradição entre o estado político e a sociedade civil, revela que os direitos humanos legitimariam, sob a capa da igualdade formal e do homem universal abstrato, os interesses egoístas de um indivíduo bastante concreto, o membro da sociedade burguesa. Em virtude do elemento ilusório das declarações, de acordo com a autora, é que precisamente essa implicação que torna os direitos humanos, aos olhos de Marx, um postulado vazio.

Marx (2010) afirma que a constituição do Estado político e a dissolução da sociedade burguesa nos indivíduos independentes - cuja relação é baseada no Direito - efetiva-se em um só e mesmo ato. Para o autor, a revolução política decompõe a vida burguesa em seus componentes sem revolucionar esses mesmos componentes nem os submeter à crítica, destacando-se que ela encara a sociedade burguesa, o mundo das necessidades, do trabalho, dos interesses privados, do Direito privado, como o fundamento de sua subsistência, como um pressuposto sem qualquer fundamentação adicional, e, em consequência, como sua base natural. Por fim,

o homem na qualidade de membro da sociedade burguesa é o que vale como o homem propriamente dito, como o homme em distinção ao citoyen, porque ele é o homem que está mais próximo de sua existência sensível individual, ao passo que o homem político constitui apenas o homem abstraído, artificial, o homem como pessoa alegórica, moral. O homem real só chega a ser reconhecido na forma do indivíduo egoísta, o homem verdadeiro, só na forma do citoyen abstrato (MARX, 2010, p. 53). 
Para Thamy Pogrebinschi (2007), são justamente esses conceitos de liberdade e de propriedade privada, tal como esculpidos na Declaração de 1789, que constituem, de acordo com Marx, o fundamento da sociedade moderna. Nesse sentido, para a autora, a Revolução Francesa viria a consolidar a emancipação política da burguesia, engendrando em si a irrupção dessa classe social sob a forma como ela se revestirá no mundo moderno. Assim, no seu entender, os direitos humanos, em cujo vértice se encontram a liberdade e a propriedade privada, consistem na garantia que a burguesia busca consolidar para tornar e manter estável a sua própria afirmação.

Desse modo, prossegue a referida autora, afirmando que o ímpeto de universalização contido na Declaração de Direitos Francesa identifica-se com a ambição, ao mesmo tempo universalista e universalizante da burguesia, de seu modo de vida, de sua hegemonia, de sua necessidade de se manter estável, de sua própria garantia como classe e enquanto a classe que detém o poder e a produção estatal de direitos. Assim, para a autora, o Estado moderno que emerge da Revolução Francesa afirma-se na forma de um Estado supostamente democrático e representativo, que reflete em sua natureza representativa a separação entre sociedade civil e Estado, e em sua natureza democrática a abstração dos direitos iguais (POGREBINSCHI, 2007).

Nesse sentido, para Letícia da Costa Paes (2011), a Revolução Francesa, portanto, consolida a emancipação política ${ }^{1}$ da burguesia, consagra o direito à propriedade e a praticar a religião, apresentou as precondições capitalistas da exploração num discurso de direitos formulado enganosamente como liberdades. No seu entender, é nesse quadro que a ideia de direitos humanos se torna indispensável para fundamentar o interesse particular e mantê-lo estável, de modo a engessar qualquer esfera de ação oposta a eles, no qual o sentido da universalização inserido no escopo destes direitos implica na ambição de universalizar o modo de vida burguês.

Assim, para a referida autora, o exercício dos direitos humanos configura-se como ficções ideológicas em que, na verdade, os interesses de uma classe da sociedade prevalecem, haja vista que o homem abstrato, sem história nem contexto, inscrito nas declarações, dá o aval para a parcialidade e a exploração, pois se supõe, em princípio, que os direitos se oponham em nome do interesse de todos. Nesse sentido, no seu entender, o que ocorre é exatamente o oposto: os direitos humanos legitimam e perpetuam um sistema de dominação estabelecido (PAES, 2011). Por fim, observa que

a esfera do Estado, portanto, aparece como a organização jurídico-política que assegura as condições de existência da exploração capitalista. (...) Isso culmina na contradição radical trazida pela Revolução Francesa entre o discurso dos direitos, apresentados como liberdades naturais, e a manutenção das precondições capitalistas da opressão. Na medida em que a forma jurídica é construída sob a proteção desses princípios e sob o argumento de que os direitos são naturais, as condições históricas e sociais pelas quais eles se ergueram são suprimidas. Os direitos humanos, defende Marx, não são naturais ou inalienáveis, mas criações históricas do Estado e da lei (PAES, 2011, p. 73).

Nessa linha, para os fins do presente ensaio, a compreensão dos direitos humanos na sociedade capitalista passa pela análise do que Marx denominou de fetichismo da mercadoria. Em que consiste tal formulação? Vejamos.

\section{A CONSTRUÇÃO DOS DIREITOS HUMANOS COMO FETICHE: ADENTRANDO NO CONCEITO COMO MERCADORIA}

Marx (2007) destaca que o primeiro ato histórico é a produção dos meios para a satisfação das necessidades humanas, a produção da própria vida material, e este é, sem dúvida, um ato histórico, uma condição fundamental de toda a História. $O$ segundo, que é a satisfação dessa primeira necessidade, a ação de satisfazê-la e o instrumento de satisfação já adquirido conduzem a novas necessidades - e essa produção de novas necessidades constitui o primeiro ato histórico. Prossegue o autor afirmando que a produção da vida, tanto da própria, no trabalho, quanto da alheia, na procriação, aparece desde já como uma relação dupla - de um lado, como relação natural, de outro como relação social - social no sentido de que por ela se entende a coo-

\footnotetext{
Na quarta parte deste artigo discutiremos os conceitos marxianos de emancipação política e humana, para fins de elucidação da emancipação do sujeito ético-moral na esfera pública.
} 
peração de vários indivíduos, sejam quais forem as condições, o modo e a finalidade. Segue-se daí, no seu entender, que um determinado modo de produção ou uma determinada fase industrial estão sempre ligados a um específico modo de cooperação ou a uma determinada fase social.

Para o filósofo alemão, "o trabalho é um processo entre o homem e a Natureza, um processo em que o homem, por sua própria ação, medeia, regula e controla seu metabolismo com a Natureza". Assim, "ao atuar, por meio desse movimento, sobre a Natureza externa a ele e ao modificá-la, ele modifica, ao mesmo tempo, sua própria natureza" (MARX, 1996). Nesse sentido, na concepção marxiana, o trabalho assume uma perspectiva ontológica, ou seja, é "uma condição indispensável da vida social, mas também é o elemento determinante para a formação do ser humano, seja como indivíduo, seja como ser social” (SELL, 2001, p. 78).

Nessa linha, na perspectiva marxiana, a mercadoria é, antes de tudo, um objeto externo, uma coisa, a qual pelas suas propriedades satisfaz necessidades humanas de qualquer espécie. De um lado, o valor de uso realiza-se somente no uso ou no consumo, constituindo-se como o conteúdo material da riqueza, qualquer que seja a forma social desta, e, na sociedade burguesa, funda, ao mesmo tempo, os portadores materiais do valor de troca, pois nele está objetivado ou materializado trabalho humano abstrato. De outro, o valor de troca mostra-se como algo casual e puramente relativo; um valor de troca imanente, intrínseco à mercadoria, independentemente do seu valor de uso (MARX, 1996). É oportuno destacar aqui que o trabalho que cria o valor de troca é, portanto, o trabalho abstrato.

José Paulo Netto (1981) afirma que o estudo marxiano da mercadoria, célula econômica da sociedade burguesa, é que propicia a captação ontológico-histórica do trabalho como constitutivo do ser social e a tomada da dimensão econômico-social particular da sociedade burguesa. No seu entender, é assim que, no contexto em que se enunciam as proposições sobre o fetichismo, articula-se, simultaneamente, a reprodução teórica do movimento histórico da categoria trabalho e a reprodução teórica do movimento histórico da categoria valor, no âmbito da emergência e consolidação do modo de produção capitalista. Por fim, observa o autor que a produção mercantil dominante, no mesmo processo em que revela o caráter social do trabalho, reveste com um envoltório a-social o seu produto.

Marx (1996) indaga-se sobre o caráter enigmático do produto do trabalho, tão logo ele assume a forma mercadoria. Para o autor, o misterioso da forma mercadoria consiste, portanto, simplesmente no fato de que ela reflete aos homens as características sociais do seu próprio trabalho como características objetivas dos próprios produtos de trabalho, como propriedades naturais sociais dessas coisas e, por isso, também reflete a relação social dos produtores com o trabalho total como uma relação social existente fora deles, entre objetos. Assim, para o autor,

a forma mercadoria e a relação de valor dos produtos de trabalho, na qual ele se representa, não têm que ver absolutamente nada com sua natureza física e com as relações materiais que daí se originam. Não é mais nada que determinada relação social entre os próprios homens que para eles aqui assume a forma fantasmagórica de uma relação entre coisas. (...) Isso eu chamo o fetichismo que adere aos produtos de trabalho, tão logo são produzidos como mercadorias, e que, por isso, é inseparável da produção de mercadorias (MARX, 1996, p. 198-199).

Para Marx (1996), esse caráter fetichista do mundo das mercadorias provém do caráter social peculiar do trabalho que produz mercadorias, no qual os objetos de uso se tornam mercadorias apenas por serem produtos de trabalhos privados, exercidos independentemente uns dos outros, observando-se que o complexo desses trabalhos privados forma o trabalho social total. Assim, no seu entendimento, aos produtores aparecem as relações sociais entre seus trabalhos privados como o que são, isto é, não como relações diretamente sociais entre pessoas em seus próprios trabalhos, senão como relações reificadas entre as pessoas e relações sociais entre as coisas.

Por outro lado, Marx (2008, p. 80-81) observa que o trabalhador, em relação ao produto do seu trabaIho, defronta-se como um ser estranho, com um poder independente do seu produtor. Para o autor, quanto mais o trabalhador se apropria do mundo exterior, por meio do seu trabalho, tanto mais ele se priva dos meios de vida, seja pela perda do objeto do seu trabalho, seja pela privação da sua subsistência física. É aqui que se coloca a questão da alienação - ou estranhamento - na qual "a propriedade privada se constitui como 
o produto, o resultado, a consequência necessária do trabalho exteriorizado, da relação externa do trabalhador com a natureza e consigo mesmo".

Observa José Paulo Netto (1981) que o traço fundamental do fetichismo é a supressão das mediações sociais que ele opera, subsumindo-as numa coisa substantiva e autônoma. Ainda, na sua concepção, a alienação desenvolve-se quando os agentes sociais particulares não conseguem discernir e reconhecer nas formas sociais o conteúdo e o efeito da sua ação e intervenção, sendo que, no limite, a sua própria motivação à ação aparecem-Ihes como alheias e estranhas (idem).

Diante de tais considerações, fica a seguinte indagação: Como se materializa o fetichismo da mercadoria no tocante aos direitos humanos? Um caminho para uma resposta adequada perpassa por apontar a funcionalidade dos direitos humanos no sistema de reprodução do capital.

Inicialmente, cabe destacar que o fetichismo da mercadoria amplia-se para todos os aspectos da vida no seio da sociedade burguesa. José Paulo Netto (1981) observa que o caráter de coisa que as relações sociais adquirem na forma mercadoria é o caráter das objetivações humanas, se coagulando numa prática social que os agentes sociais particulares não reconhecem como suas. Assim, para o autor, o fetichismo mercantil passa a ser fetichismo de todo o intercâmbio humano.

Robert Kurz (2003) afirma que é o mercado universal que forma o fundamento de todos os direitos, incluindo os direitos humanos elementares. Nesse sentido, para o autor, a guerra pela ordem do mundo, que mata pessoas, é conduzida em prol da liberdade dos mercados, que igualmente mata pessoas e, com isso, também em prol dos direitos humanos, visto que estes não são imagináveis sem a forma do mercado. Daí o porquê de o autor alemão considerar uma relação paradoxal dos direitos humanos: reconhecimento por meio do não reconhecimento, ou, inversamente, não reconhecimento justamente por meio do reconhecimento.

Para o referido autor, a aparente contradição se resolve na medida em que descortinamos a concepção de ser humano na lógica do capital. Nesta lógica, nos termos do autor, o ser humano é, em tese, um ser solvente, o que significa, por consequência, que um indivíduo inteiramente insolvente não pode ser em princípio um ser humano. De acordo com o autor, a capacidade de entrar numa relação jurídica está ligada, portanto, à capacidade de participar de alguma maneira no processo de valorização do capital, satisfazendo o critério da rentabilidade, pressuposto tácito dos direitos humanos (KURZ, 2003).

No entender de Kurz (2003), pode-se observar aí um duplo entrelaçamento paradoxal de reconhecimento e não reconhecimento na forma do direito moderno, pois o direito implica, segundo sua essência, uma relação de inclusão e exclusão, destacando-se que o universal é somente a pretensão ao domínio absoluto dessa forma. Assim, para o autor, o ser humano em geral visado pelos direitos humanos é o ser humano meramente abstrato, ou seja, o ser humano na condição de portador e ao mesmo tempo escravo da abstração social dominante, e somente como este ser humano abstrato ele é universalmente reconhecido. Para Robert Kurz (2003):

Isso significa que esse reconhecimento inclui simultaneamente um não-reconhecimento: as carências materiais, sociais e culturais são excluídas justamente do reconhecimento fundamental. O homem dos direitos humanos é reconhecido apenas como um ser reduzido à abstração social; O famoso "reconhecimento" é na realidade uma pretensão totalitária à vida dos indivíduos, que são forçados a sacrificar abertamente sua vida para o fim, tão banal quanto realmente metafísico, da valorização sem fim do dinheiro através do "trabalho" (KURZ, 2003).

Por fim, para Kurz (2003), a promessa dos direitos humanos é desde sempre uma ameaça: se não podem ser preenchidas as condições tácitas que definem na modernidade o ser humano, então deve faltar o reconhecimento, contudo tal quadro pode forçar a maioria das pessoas à autorrenúncia, que consiste em acatar a submissão à forma abstrata do dinheiro e do direito.

No mesmo sentido, Slavoj Zizek (2010) sintetiza a relação do fetichismo da mercadoria com os direitos humanos, ao observar que em uma sociedade na qual predomina a troca de mercadoria, os indivíduos, em sua vida diária, fazem referência a si mesmos e aos objetos que encontram como personificações contingentes de noções universais abstratas. No seu entender, o que é o ser humano, em relação às experiências sociais e culturais concretas, é vivenciado como contingente, pois o que o define fundamentalmente é a capacidade universal abstrata de pensar ou de trabalhar. 
Robert Kurz (1998) afirma que existe um sonho característico da modernidade: o sonho da emancipação social, da autodeterminação do homem, de uma produção autônoma da vida. Pondera que o próprio mercado é o responsável pela sujeição dos homens à ditadura muda do dinheiro e da rentabilidade econômica, uma vez que o sistema híbrido composto pelo Estado e mercado não é mais capaz de integrar socialmente milhões de pessoas em todo o mundo, estando condenado a deixar de ser a forma predominante de sociedade.

Antonio Carlos da Silva e Vanessa Cavalcanti (2015) observam que a não valorização da vida como opção é uma afronta ao sujeito ético-moral, haja vista que o não reconhecimento (absoluto ou relativo) do indivíduo retira de sua essência o valor mais precioso: a humanidade. Para os autores, o real desenvolvimento propriamente dito infere ao recorrer na essência da humanidade, qual seja, a emancipação de toda e qualquer espécie de coisificação. Por essa razão, no seu entender, a crítica do próprio conceito de política é uma condição sine qua non para superar a peste/capital e poder interpretar as folhas de nosso devir histórico como algo novo e histórico.

Feitas tais considerações, passaremos a analisar, no contexto da modernidade burguesa, a separação entre a ética e a política, que põe em evidência a problemática da liberdade, para correlacionar com o fetiche dos direitos humanos e a emancipação do sujeito ético-moral.

\section{A SEPARAÇÃO ENTRE A ÉTICA E A POLÍTICA NA MODERNIDADE}

A modernidade, segundo Marilena Chauí (2007), é caracterizada, como paradigma, pelo privilégio da razão e da universalidade, pelo positivismo, pela crença no progresso linear da civilização e em verdades absolutas, pela continuidade temporal da história, pelo planejamento racional e duradouro da ordem social e política e pela padronização dos conhecimentos e da produção econômica como sinais da universalidade. Nessa linha, de acordo com Chauí (op.cit.), a modernidade acreditaria na importância de constituir o poder político como esfera pública separada da sociedade civil e capaz de regulá-la por intermédio do Estado.

Chauí (2007) destaca que a modernidade afasta a ideia (medieval e renascentista) de um universo regido por forças espirituais secretas, razão pela qual o mundo se desencanta e passa a ser governado por leis naturais racionais e impessoais que podem ser conhecidas pela razão e que permitirão aos homens o domínio técnico sobre a natureza. No seu entender, a modernidade conserva a ideia de que a virtude é obediência à razão, que virtude é dever e obrigação diante de normas e valores universais e que a liberdade é o poder humano para enfrentar com suas próprias forças a contingência e a diversidade.

Chauí (2007) frisa que a modernidade, inventando a ideia do indivíduo livre, torna problemático o conceito de valores éticos universais, pois aquele é, na verdade, membro de uma ordem social definida, agora, por um centro organizador, o mercado. Segundo a autora, o mercado precisa do conceito de indivíduo livre que se relaciona com os outros por meio de uma relação contratual, dotada de validade apenas se os contratantes forem livres e iguais. Em virtude de o mercado ser o centro ordenador da nova realidade, surge uma problemática no campo ético, de como definir a virtude pelo domínio racional da vontade sobre as paixões.

Para o enfrentamento de tal questão, Marilena Chauí (2007) alerta que a materialidade particularista dos interesses e das paixões seria substituída pela formalidade absoluta dos valores éticos, mas, com isso, ética e vida sociopolítica tornaram-se incompatíveis. Em outras palavras, a autora consigna que a moral do imperativo ético garante a liberdade e a responsabilidade éticas como valores universais, mas pagando o preço de não corresponder às exigências cotidianas da prática. É por esse caminho que se delineia a separação entre a ética e a política. Vejamos.

Hannah $\operatorname{Arendt}^{2}$ (2006) afirma que a liberdade não é apenas um entre muitos outros fenômenos e problemas da esfera política propriamente dita; a liberdade torna-se o alvo direto da ação política, pois constitui

\footnotetext{
Gilson Dantas (2013, p. 4-10) observa que a autora, em A Condição Humana, faz, de um lado, uma forte e apaixonada crítica à sociedade moderna e, por outro, questiona a categoria trabalho em Marx, sendo que o pensamento deste teria um viés totalitário e se fundaria numa concepção estreita e reducionista da categoria trabalho (estenderia a visão instrumental do trabalho ao conjunto da sociedade e da cultura), o que indicaria o seu distanciamento em relação à liberdade, à vida política e à pluralidade (múltiplas individualidades) próprios da condição humana. Contrário a tal entendimento, o autor pontua que a categoria trabalho em Marx não aparece como algo que subsume as demais atividades humanas, que a elas se sobrepõe, as concentra e absorve; em Marx, o trabalho propicia a humanização do homem, a transição de espécie animal a ser social, funda as determinações do social (no sentido ontológico) e, ao mesmo tempo, é entendido em suas múltiplas dimensões.
} 
o motivo pelo qual os seres humanos vivem juntos no seio de organizações políticas. De acordo com a autora, o propósito da política é a liberdade, e o seu campo de experiências é a ação. Assim, no seu entender, a liberdade requeria, para além da mera libertação das necessidades da vida, a companhia de outros homens que estivessem no mesmo estado, assim como um espaço público comum, ou seja, um mundo politicamente organizado, no qual os homens livres pudessem integrar-se por meio da ação e da palavra.

Para a referida autora, sem uma esfera pública politicamente garantida, a liberdade fica sem espaço onde emergir, pois, enquanto fato demonstrável, a liberdade coincide com a política, e as duas estão intimamente relacionadas. Por essa razão, pondera a autora que a liberdade em sua relação com a política não é um fenômeno da vontade (ARENDT, 2006).

Voltando a Marilena Chauí (2007), destaca-se sua sinalização para o problema moderno da relação entre a ética e a política, na qual a primeira é colocada pela modernidade como esfera da vida privada e, a segunda, como esfera da vida pública. Nessa linha, de acordo com a autora, a contradição entre o público e o privado centra-se na seguinte indagação: Os fins justificam os meios? No caso da ética, afirma a autora, a resposta seria negativa, pois para fins éticos os meios precisam ser éticos também. Por outro lado, para a política, todos os meios são bons e lícitos, se o fim for bom para a coletividade. Em suma, no entender de Chauí, o pressuposto da separação e o pressuposto da regulação proporcional entre meios e fins significa que se está considerando a ética e a política como técnicas e não como práxis.

Diante de tais considerações a respeito da separação da ética e da política, como relacionar mais diretamente com a ética - ou o espírito - do capitalismo? Qual a sua funcionalidade para a compreensão dos direitos humanos como fetiche?

Marilena Chauí (2007) sinaliza que o pensamento liberal precisou oferecer expressão política para questões que eram puramente éticas, particularmente uma: a da tirania ou despotismo das paixões, concepção herdada da ética cristã e estoica que define a paixão como vício e fonte da discórdia no interior do indivíduo e da comunidade. Indaga-se a autora: Como o capitalismo poderia propor uma ética comunitária e do interesse geral, se é fundado na competição, na propriedade privada dos meios de produção, na divisão social das classes, na exploração econômica, no lucro e na desigualdade social? Como poderia, em termos hegelianos e marxistas, criar uma política do espaço público, se seus pressupostos são o direito privado, a vontade privada, a ética individual e individualista?

Nessa linha, afirma que foi preciso criar instituições políticas que canalizassem para o bem comum esse crescimento e essa expansão do interesse privado, dado que, em lugar de opor o público ao privado, o capitalismo fez deste o instrumento daquele, com um arranjo institucional astucioso que estabeleceu a adequação da ética privada para fins públicos, visando a conciliar os interesses privados expansionistas - de uma classe - com a estabilidade, a ordem e a paz sociais (CHAUÍ, 2007).

No mesmo sentido, Hannah Arendt (2006) observava que o liberalismo teve a sua cota-parte na expulsão do conceito de liberdade da esfera política, pois a política, segundo a Filosofia, deve se preocupar quase que exclusivamente com a preservação da vida e a salvaguarda dos seus interesses. Frisa a autora que, onde a vida está em risco, toda a ação está por definição sob o jugo da necessidade, e o domínio próprio para se tratar das necessidades da vida é a esfera gigantesca (e em contínuo crescimento) da vida econômica e social, cuja administração lançou a sua sombra sobre a esfera política logo depois do início da era moderna. $\mathrm{O}$ que a autora acentua é que, num contexto de ampla desigualdade socioeconômica - ausência quase completa das condições materiais de vida em sociedade - em que pese a ampliação formal dos direitos humanos, a própria liberdade do ser humano está em risco, ou seja, a política não cumpre a sua finalidade.

Robert Kurz ${ }^{3}$ (1994) observa que a veemência político-econômica explica também por que a esfera política como tal não pôde desaparecer com o fim histórico da fase ascendente do sistema produtor de merca-

Robert Kurz, de acordo com Ricardo Regatieri (2009), recupera, reformula e expande a crítica marxiana do valor e do fetichismo e perscruta a mediação da teoria crítica, realizando uma crítica aos fundamentos da modernidade. Por outro lado, observa Ricardo Antunes (1994) que o autor alemão, em o Colapso da Modernização (1994), questiona a centralidade do trabalho no mundo contemporâneo, focando na eliminação da centralidade do trabalho abstrato. Segundo Antunes, Kurz centra toda a sua análise na prevalência da produção generalizada e destrutiva de mercadorias e na consequente teoria marxiana do valor-trabalho. Apesar de discordar em parte com o referido autor, afirma que o livro é um alento e um reflexão viva na direção de uma formulação inconformada e anticapitalista. 
dorias, para dar lugar a uma concertação socioeconômica direta de interesses na forma da mercadoria. De acordo com o autor, não seria a política como tal que desaparece com a afirmação do sistema, mas só a sua dupla função e a ênfase aparentemente autonomizada, as suas vestes ideológicas, permanecendo, porque inevitável e ineliminável na base do sistema, a política como função secundária no processo contínuo de automediação da forma da mercadoria agora incontestada, ubíqua e total. Assim, o fato de a política ficar como um resíduo resulta do carácter fetichista deste processo.

De acordo com Kurz (1994), a política é uma simples forma de mediação de algo que a transcende, sobre o qual ela, como política, não tem poder autônomo. A falência definitiva da política, segundo o autor, nunca foi, nesse sentido, superada ou protelada por meio de medidas políticas, mas sempre e apenas mediante um ulterior avanço histórico da valorização do dinheiro, independentemente de toda a política. No seu entender, não será a política a efetuar de novo um pretenso controle sobre a economia ou uma pretensa suspensão totalitária da circulação, mas, precisamente ao contrário, o fim catastrófico da política.

Nessa linha, Marilena Chauí (2007) sinaliza que, no âmbito de um neoliberalismo pós-moderno, marcado pela veloz desintegração do espaço público sob os imperativos da dispersão econômica, a privatização do público se realiza pela perda de sentido e de poder de todas as instituições políticas capazes de servir como mediação entre o poder executivo e a sociedade. No seu entender, privatização significa desinstitucionalização do espaço público e corresponde ao fortalecimento dos centros privados, onde se dá a decisão econômica e o enfraquecimento dos Estados Nacionais. Nessa linha, o esfacelamento da esfera pública, na qual "a liberdade é um valor ético porque é um valor político" (Idem, p. 499), põe em evidência a discussão sobre a emancipação política e a emancipação humana, conforme delineado pela teoria marxiana.

\section{A EMANCIPAÇÃO DO SUJEITO ÉTICO-MORAL}

Para Thamy Pogrebinschi (2007), há uma importante distinção entre a emancipação humana e a emancipação política, que corresponde à cisão entre o homem e o cidadão: ao emancipar-se politicamente, o homem o faz mediante um subterfúgio, através de um meio, mesmo que seja um meio necessário - o Estado. Na emancipação política, o Estado funciona como mediador entre o homem e a sua liberdade.

Nesse sentido, no entender da autora, a emancipação política é uma forma limitada de emancipação. Essa limitação, ou parcialidade, observa a autora, explica-se na medida em que a emancipação política é apenas uma parte da emancipação humana e, mais do que isso, não é nem um modo radical nem um modo isento de contradições. Por outro lado, a emancipação humana almejada por Marx, pondera a autora, implica o retorno do homem sobre si mesmo como ser social e, por isso, humano (POGREBINSCHI, 2007).

Karl Marx (2010), numa análise sobre os limites da cidadania judaica, observa que a emancipação política do judeu, do cristão, do homem religioso de modo geral consiste na emancipação do Estado em relação ao judaísmo, ao cristianismo, à religião como tal. No seu entender, a emancipação política em relação à religião não é a emancipação já efetuada, isenta de contradições, em relação à religião, porque a emancipação política ainda não constitui o modo já efetuado, isento de contradições, da emancipação humana. Para o autor, o limite da emancipação política fica evidente de imediato no fato de o Estado ser capaz de se libertar de uma limitação sem que o homem realmente fique livre dela, ou em outras palavras, sem que o homem seja um homem livre. Nesse sentido, sinaliza que

a emancipação política de fato representa um grande progresso; não chega a ser a forma definitiva da emancipação humana em geral, mas constitui a forma definitiva da emancipação humana dentro da ordem mundial vigente até aqui. Que fique claro: estamos falando aqui de emancipação real, de emancipação prática. (...). Todavia, não tenhamos ilusões quanto ao limite da emancipação política. A cisão do homem em público e privado, o deslocamento da religião do Estado para a sociedade burguesa, não constitui um estágio, e sim a realização plena da emancipação política, a qual, portanto, não anula nem busca anular a religiosidade real do homem (MARX, 2010, p. 41-42).

Marx (2010) observa que a emancipação política representou concomitantemente a emancipação da sociedade burguesa em relação à política, até em relação à aparência de um teor universal. Nessa linha, assim reflete tal questão, vejamos: 
A emancipação política é a redução do homem, por um lado, a membro da sociedade burguesa, a indivíduo egoísta independente, e, por outro, a cidadão, a pessoa moral. Mas a emancipação humana só estará plenamente realizada quando o homem individual real tiver recuperado para si o cidadão abstrato e se tornado ente genérico na qualidade de homem individual na sua vida empírica, no seu trabalho individual, nas suas relações individuais, quando o homem tiver reconhecido e organizado suas "forces propres" [forças próprias] como forças sociais e, em consequência, não mais separar de si mesmo a força social a forma da força política (MARX, 2010, p. 53-54).

É nesse sentido que Ivo Tonet (2005) observa que a emancipação humana é algo muito distinto da cidadania e da totalidade da emancipação política. No seu entendimento, a emancipação humana, ou seja, uma forma de sociabilidade na qual os homens sejam efetivamente livres, supõe a erradicação do capital e de todas as suas categorias, sem a qual é impossível a constituição de uma autêntica comunidade humana. Por outro lado, pontua que essa erradicação não significa, de modo algum, o aperfeiçoamento da cidadania, mas, ao contrário, a sua mais completa superação. No mesmo sentido pondera Tomás Bastian de Sousa (2008) que a emancipação humana plena seria a reabsorção do cidadão abstrato pelo homem real e individual, na qual o indivíduo real, na sua vida cotidiana, no trabalho e nas suas relações intersubjetivas, tiver se tornado um ser genérico.

Assim, na perspectiva marxiana, os direitos do homem não se constituem como uma categoria universal, atemporal e permanente, ou natural, mas sim como uma construção histórica, no interior de uma ordem societária capitalista. Seus limites intrínsecos impedem a emancipação humana, uma vez que, na sua forma extremada - emancipação política - somente reitera o ser humano como um ser abstrato, destituído de sua liberdade, no sistema de reprodução do capital.

\section{CONSIDERAÇÕES FINAIS}

Neste artigo buscamos evidenciar como o ideário dos direitos humanos no âmbito da sociedade capitalista se apresenta como um discurso fetichizado, de um lado, servindo historicamente no processo de legitimação da ordem burguesa, como promessa da modernidade, e, de outro, que o seu conceito de ser humano está sedimentado sob a ótica da funcionalidade do capital, em detrimento do sujeito ético-moral.

No mesmo sentido, analisamos como a separação entre a ética e a política na modernidade foi funcional para a consolidação e ampliação da ética do mercado. Destacamos que, num contexto de ampla desigualdade socioeconômica provocada pelo capitalismo - ausência quase completa das condições materiais de vida em sociedade - em que pese a ampliação formal dos direitos humanos, a própria liberdade do ser humano está em risco, ou seja, a política não cumpre a sua finalidade.

Em suma, a emancipação do sujeito ético-moral para além do capital deve restituir a humanidade ao ser humano, demasiadamente abstrato na sociedade burguesa, na qual este volte a ser um ser social, rompendo com o fetichismo e a alienação que o aprisiona como um servo do capital, reconhecendo-se na sua subjetividade e na sua relação com o outro.

\section{REFERÊNCIAS}

ANTUNES, Ricardo. Resenha de: KURZ, Robert. O colapso da modernização: da derrocada do socialismo de caserna à crise da economia mundial. Rio de Janeiro: Paz e Terra, 1992. 244 p. Crítica Marxista, São Paulo, Brasiliense, v. 1, n. 1, p. 135-141, 1994. ARENDT, Hannah. O que é a liberdade. In: ARENDT, Hannah. Entre o passado e o futuro: oito exercícios sobre o pensamento político. Lisboa: Relógio D’Água, 2006. p. 155-182.

BALIBAR, Étienne. A filosofia de Marx. Rio de Janeiro: Jorge Zahar Editor, 1995.

CHAUÍ, Marilena. Público, privado e despotismo. In: NOVAES, Adauto (org.). Ética. São Paulo: Companhia das Letras, 2007. p. 488-557.

DANTAS, Gilson. A crítica de Hannah Arendt à Karl Marx. Revista Sociologia em Rede, v. 3, n. 3, p. 2-18 2013.

KURZ, Robert. Os paradoxos dos direitos humanos: inclusão e exclusão na modernidade. 2003. Disponível em: http://obeco. planetaclix.pt/rkurz116.htm

KURZ, Robert. Os últimos combates. 4. ed. Petrópolis: Editora Vozes, 1998. 


\section{Direito自 \\ Debate}

KURZ, Robert. O fim da política: teses sobre a crise do sistema de regulação da forma mercadoria. 1994. Disponível em http:// obeco.planetaclix.pt/rkurz105.htm

MARX, Karl. Sobre a questão judaica. São Paulo: Boitempo, 2010.

MARX, Karl. Manuscritos econômico-filosóficos. São Paulo: Boitempo, 2008.

MARX, Karl. A ideologia alemã. São Paulo: Boitempo, 2007.

MARX, Karl. O capital - crítica da economia política. São Paulo: Editora Nova Cultural, 1996. (Coleção Os Economistas). Volume I. NETTO, José Paulo. Capitalismo e reificação. São Paulo: Livraria Editora Ciências Humanas, 1981.

PAES, Letícia da Costa. A política dos direitos humanos: entre paradoxos e perspectivas. 2011. Dissertação (Mestrado em Direito) - Pontifícia Universidade Católica do Rio de Janeiro, Rio de Janeiro, 2011.

POGREBINSCHI, Thamy. O direito entre o homem e o cidadão. Marx e a crítica dos direitos humanos. Revista de Direito do CeSUSC, n. 2, jan./jun. 2007.

REGATIERI, Ricardo P. Negatividade e ruptura: configurações da crítica de Robert Kurz. 2009. Dissertação (Mestrado em Sociologia) - Universidade de São Paulo. São Paulo, 2009.

SELL, Carlos Eduardo. Sociologia clássica: Durkheim, Weber e Marx. Itajaí: Vozes, 2011.

SILVA, Antonio Carlos da; CAVALCANTI, Vanessa. Diálogos abertos e teoria crítica: por uma "aventura" emancipatória. Revista Dialética, v. 6, a. 5, p. 66-78, jun. 2015.

SOUSA, Tomás Bastian de. Política e direitos humanos em Marx: da questão judaica à ideologia alemã. 2008. Dissertação (Mestrado em Filosofia) - Universidade de São Paulo. São Paulo, 2008.

TONET, Ivo. Cidadania ou emancipação humana. Revista Espaço Acadêmico, n. 44, jan. 2005.

ZIZEK, Slavoj. Contra os direitos humanos. Mediações, Londrina, v. 15, n. 1, p. 11-29, jan./jun. 2010. 